\title{
The Way
}

\section{See It}

\section{We must be a part of international librarianship}

\author{
By Hannelore B. Rader
}

\section{Librarians can belp develop global communication of the future}

hope there is enough intelligence in the human organism to make a small leap toward more cooperation between peoples and nations. Otherwise, we won't be around for the next really big leap" (Andrew Greeley in Angelfire).

This statement points to the importance of international cooperation not only for the world to survive, but also to ensure global communication and information sharing. In this age of information and technology, physical, emotional, and economic survival is of global concern. With the emergence of worldwide communication systems, information anywhere in the world can be made available instantly to everyone who is willing and able to listen, look, or read. Though libraries are regarded as important information providers throughout the world, unfortunately many people are still either unaware of this idea or do not accept it.

Often in discussions about the importance of scholarly communication in the age of technology, the importance of libraries and librarians is not apparent. It is predicted that in a very short time scholars will be able to communicate and collect information for research electronically and on an international level. With the help of computer and telecommunication technologies, as well as artificial intelligence, workstations are being developed and linked worldwide to create global systems of scholarly and user-friendly communication. Librarians must become involved in this development and similar cooperative efforts worldwide. Librarians must ensure that scholars as well as all citizens will have access to global informa- tion and communication resources developed and maintained by expert information specialists, using global information technologies and access to effective and efficient information delivery systems worldwide.

More U.S. librarians must assume a vital global role in the development of national and international standards, software and information evaluation methodologies, copyright license agreements, full-text electronic publishing and preservation, and helping people to become information literate. In addition, they must take the initiative to work with ethnic, minority, and international groups within the U.S., Canada, and Mexico, with the ultimate goal of creating citizens who are information literate.

The American Library Association (ALA), the world's largest professional organization for librarians, must take a leadership role in these important endeavors to place librarians in the forefront of information technology development and utilization. Although ALA has been involved in international relations since its first annual conference in 1876 and supports a successful Book/Fellow program funded by the U.S. Information Agency, ALA must intensify these efforts if U.S. librarianship is to assume a. vital international role.

Many librarians, especially those new to the profession, continue to express their interest in international librarianship through work exchanges overseas, visits, and study tours. But ALA does not provide a central place to handle such exchanges. In 1985 ALA's International Relations Committee and the International Round Table formed a joint subcommittee on international exchanges for librarians and information professionals. This group has addressed a number of needs and recently published Going International, a librarian's guide

(Cont. on page 244) 
Figure 1

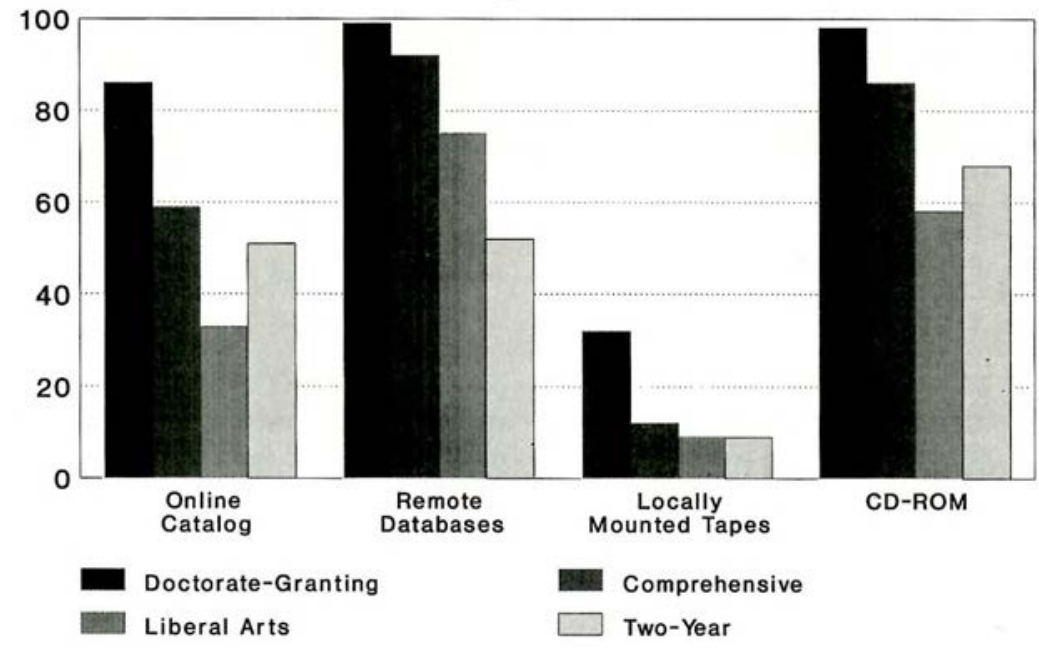

\section{Figure 1. Percentage of respondents offering searching of computerized catalogs and databases, by type of source.}

and Statistics (ORS) and ACRL hope to gather data on access technologies again in a few years. Will we want to ask about the same four technologies? Or will other access technologies be much more important then?

\section{(Rader cont. from page 242)}

for work experience and job exchange abroad. Likewise other library associations are establishing international committees and taskforces to address library-related international concerns. But much more work is needed on a broader scale to develop international library cooperation and information sharing, and ALA must assume a leadership role in this area.

American librarians need to support international library activities in terms of global information technologies. They must become leaders in building the global library community and share their library expertise with library communities in underdeveloped countries and newly emerging democracies. This becomes especially important at a time when many U.S. citizens see more of an isolationist role for the U.S. in world affairs.

It is noteworthy that U.S. librarians' interest in international activities continues to grow, especially since Eastern Europe has changed so dramatically. Our international colleagues
Ed. Note: Alternative Sources of Revenue in Academic Libraries is available for $\$ 10$ from: Order Department, American Library Association, 50 E. Huron St., Chicago, IL 60611; (800) 545-2433. ISBN: 0-8389-5742-0.

are hoping that we will share our experience, expertise, and resources with them to guide them in the development of their own library and information services. To help bring this about, we must work toward increasing the number of libraries and institutions which will actively support exchanges with foreign librarians or offer internships and practica. We must also internationalize the curricula in the library schools across the country to provide future librarians with the understanding of and skills to deal with international library and information concerns.

Through new electronic information and communication technologies the world is becoming a global information village, and libraries must be a vital part of that development. Librarians must be deeply and meaningfully involved in helping to shape the global information/scholarly community of the future. Only through involvement in international library and information activities can we ensure this will happen. 